\title{
Inheritance and Linkage Relationships of Morphological and Isozyme Loci in Lentil (Lens Miller)
}

\author{
F. J. Muehlbauer, N. F. Weeden, and D. L. Hoffman
}

\begin{abstract}
Allozyme polymorphisms for 18 loci are described and their monogenic inheritance Is demonstrated. We Investigated linkage relationships among the 18 isozyme locl as well as four genes controlling morphological traits. Six small linkage groups were identfled, containing 14 of the locl analyzed. Several of these groups appear to be conserved between Lens and Pisum, indicating that this intergeneric comparison may expedite genetlc studies and breeding programs in both crops.
\end{abstract}

Lentil (Lens culinaris Medik.) is an important food legume in the Middle East, northern Africa, central and western Asia, and North and South America, where the crop is grown in semiarid regions, usually in rotation with cereals. The crop is valued as a high-protein food and for its residues, which are used in animal feeding. Germ plasm for breeding has been made available from systematic collection of land races and indigenous wild species in centers of diversity. Ladizinsky et al. ${ }^{5}$ showed that the wild species of Lens belong to two biological species: $L$. culinaris and $L$. $n i-$ gricans. Hybridization within $L$. culinaris, the species containing the cultigen $L$. $\mathrm{Cu}$ linaris ssp. culinaris, and two closely related subspecies, odemensis and orientalis, was easily accomplished, leading to fertile progenies. Hybridization across the biological species could be accomplished only through the use of embryo rescue. ${ }^{3}$

Even though the lentil has been an important food legume for centuries, genetic studies have been made only recently. Muehlbauer and Slinkard ${ }^{6}$ reviewed the genetics of Lens and listed 12 genes responsible for morphological and seed variation. Skibinski et al. ${ }^{9}$ identified allozymic variation at an aspartate aminotransferase locus which they designated Aat-1. Zamir and Ladizinsky ${ }^{19}$ described the inheritance of eight allozyme polymorphisms and the presence of two linkage groups. In one of these linkage groups, the gene for green epicotyl, Gs, was placed 14 map units from Got-2 (Aat-1 of Skibinski et al. $\left.{ }^{9}\right)$ and 25 map units from a gene coding an isozyme of malic enzyme, $M e-1$. More recently, Tadmor et al. " summarized linkage relationships among 15 isozyme loci, four loci encoding seed proteins, two morphological markers, and a translocation break point. Hoffman et al. ${ }^{4}$ identified several other allozyme polymorphisms within the $L$. culinaris subspecies. We report the further characterization and genetic analysis of these and other polymorphisms using hybrid $F_{2}$ populations. Four morphological characters, two of which have not been reported in previous studies, also were included in our analysis.

\section{Materials and Methods}

We used the $F_{2}$ populations from seven different crosses for this investigation. Four crosses had $L$. culinaris ssp. culinaris $\mathrm{cv}$ 'Brewer' as the maternal parent and one of four L. culinaris ssp. orientalis accessions (Nos. 4, 59, 66, and 77) as the paternal parent. $L$. culinaris ssp. culinaris $\mathrm{cv}$ 'Giza 9 ' was used twice as the maternal parent in crosses with $L$. culinaris ssp. orientalis No. 78 and $L$. culinaris ssp. odemensis No. 61. The seventh cross was $L$. culinaris ssp. culinaris cv. 'Red Chief' $\times L$. culinaris ssp. orientalis No. 78. The parents of these crosses were known to differ for several morphological genes (Table 1) and several isozyme loci. Plants from the seven $F_{2}$ populations were scợed visually fơr morphological markers, and allozyme segregation was determined by means of horizontal starch gel electrophoresis.

We prepared samples for electrophoresis using two extraction buffers, as described by Weeden and Emmo. ${ }^{12}$ Samples extracted in TRIS-maleate ( $\mathrm{pH} \mathrm{8.0)}$ buffer (Buffer I) were placed on a pH 8.1 TRIScitrate/lithium borate system. ${ }^{7}$ The potassium phosphate extraction buffer $(\mathrm{pH} 7.0)$ 
Table 1. Morphological markers in parental lines of Leno

\begin{tabular}{|c|c|c|c|c|}
\hline \multirow[b]{2}{*}{ Parent } & \multicolumn{4}{|c|}{ Marker genes" } \\
\hline & $Y c$ & $G h$ & Gs & $P i$ \\
\hline 'Brewer' & -0 & - & - & - \\
\hline 'Giza 9' & + & - & - & - \\
\hline 'Red Chief & + & - & - & - \\
\hline L. culinaris ssp. orientalis (No. 4) & + & + & - & + \\
\hline L. culinaris ssp. onentalis (No. 59 ) & + & + & + & + \\
\hline$L$ culinaris ssp. orrentalis (No. 77 ) & + & + & + & + \\
\hline L culinaris ssp. orientalis (No. 78 ) & + & + & + & + \\
\hline$L$ culinans ssp. orientalis (No. 66) & + & + & + & + \\
\hline L. aulinaris spp. odemensis (No. 61) & - & + & - & + \\
\hline
\end{tabular}

- For a description, see Muehlbauer and Slinkard.

$b+$ dominance; - - recessiveness.

was used for samples placed on a $\mathrm{pH} 6.5$ histidine gel ${ }^{1}$ and a $\mathrm{pH} 6.1$ citrate/N-(3aminopropyl)-morpholine gel. ${ }^{2}$ Slices from the TRIS-citrate/lithium borate, $\mathrm{pH} 8.1$, gel were stained for aspartate aminotransferase (AAT, EC 2.6.1.1), N-acetyl glucosaminidase (NAG, EC 3.2.1.30), peroxidase (PRX, EC 1.11.1.7), leucine amino-peptidase (LAP, EC 3.4.11.1), alcohol dehydrogenase (ADH, EC 1.1.1.1), aldolase (ALDO, EC 4.1.2.13), $\beta$-D-galactosidase (GAL, EC 3.2.1., pH 8.5), glucosephosphate isomerase (GPI, EC 5.3.1.9), and phosphoglucomutase (PGM, EC 2.7.5.1). Slices from the histidine gel were stained for fructokinase (FK, EC 2.7.1.4), 6-phosphogluconate dehydrogenase (6PGD, EC 1.1.1.44), and shikimic dehydrogenase (SKDH, EC 1.1.1.25). We assayed the cathodal slide of the pH 6.1 gel for GAL, pH 4.5 (EC 3.2.1.23).

For most enzyme systems, we used extracts from approximately $2 \mathrm{~cm}^{2}$ of young, newly expanding leaf tissue from greenhouse-grown plants for analysis. The leaf tissue was ground in approximately $0.2 \mathrm{ml}$ of extraction buffer using a Plexiglas rod. Grinding was performed in 7-ml polystyrene weigh boats that were kept on ice during the extraction. Extracts were used immediately after grinding. The greenhouse used to grow the plants was kept at $25^{\circ} \mathrm{C}$ during the day and $18^{\circ} \mathrm{C}$ at night. The natural photoperiod was extended to $16 \mathrm{~h}$ with supplemental cool white fluorescent lighting, which provided photosynthetically active irradiance of at least $145 \mathrm{~W}$ $\mathrm{m}^{-2}$ (400 to $\left.700 \mathrm{~mm}\right)$ at pot level. Extracts from root samples were used to assay for NAG, PRX, and ADH. To induce ADH, pots of plants were immersed in water for $18 \mathrm{~h}$ at room temperature before sampling. For the sampling of young root tissue, the pot was removed from the water and inverted, and the pot was gently removed from the clump of soil to expose young, actively growing roots. Approximately $2 \mathrm{~g}$ of young root tissue was sampled for each plant. For analysis of PRX isozymes, 2-mercaptoethanol was omitted from the extraction buffer.

The assays for ADH, 6PGD, and LAP were identical to or slight modifications of those described by Shaw and Prasad. ${ }^{8}$ The assays we used for AAT, ALDO, GPI, PGM, and SKDH were described by Weeden and Gottlieb. ${ }^{13}$ PRX was assayed according to the method of Weeden and Marx. ${ }^{16}$ The NAG assay contained $10 \mathrm{ml} 0.1 \mathrm{M}$ sodium

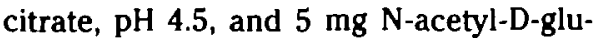
cosaminide. The GAL, $\mathrm{pH} 4.5$, assay contained $10 \mathrm{ml} 0.1 \mathrm{M}$ sodium citrate, $\mathrm{pH} 4.5$, and $5 \mathrm{mg}$ 4-methylumbelliferyl-D-galactoside dissolved in $1 \mathrm{ml}$ dimethylformamide. Both solutions were mixed together just before staining. The GAL, $\mathrm{pH} 8.5$, assay was similar to the GAL, pH 4.5, assay except that the buffer was $10 \mathrm{ml} 0.1 \mathrm{M}$ TRIS$\mathrm{HCl}, \mathrm{pH}$ 8.5. The NAG, GAL, pH 4.5, and GAL, pH 8.5, assays were poured directly onto the gel slice on a glass plate. Assay solutions were poured off after $10 \mathrm{~min}$, and the activity bands were then visualized under UV light ( $\lambda=302 \mathrm{~nm}$ ).

An agarose overlay was used for the FK assay. The FK assay was prepared by mix-

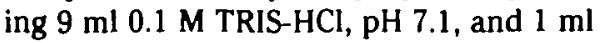
$0.1 \mathrm{M} \mathrm{MgCl}_{2}$. Low-gelling-temperature agarose (SeaPlaque, FMC, Rockland, Maine, $80 \mathrm{mg}$ ) was added to $6 \mathrm{ml}$ of buffer that was brought to a boil over low heat and held in a $37^{\circ} \mathrm{C}$ water bath. To the remaining $4 \mathrm{ml}$ of buffer, $25 \mathrm{mg} \beta$-D-fructose, $12 \mathrm{mg}$ adenosine 5 '-triphosphate, 30 units phosphoglucose isomerase, 10 units glucose 6-phosphate dehydrogenase, $5 \mathrm{mg}$ nicotinamide-adenine dinucleotide phosphate (NADP), $0.5 \mathrm{mg}$ MTT, and $0.5 \mathrm{mg}$ meldola blue were added. The two solutions were combined and immediately poured onto the gel slice on a glass plate.

The subcellular compartmentalization of the individual isozymes of AAT, ALDO, GPI, 6PGD, PGM, and SKDH was determined by the use of pollen extracts and isolation of cell fractions greatly enriched for plastids or mitochondria. Pollen leachates were obtained from freshly collected pollen, as described by Weeden and Gottlieb. ${ }^{14}$ Chloroplast and mitochondrial pellets were obtained by differential centrifugation of leaf extracts on a Sorvall RC-2B refrigerated centrifuge. Isolation of the chloroplast pellet was performed as described by Weeden and Robinson. ${ }^{18}$ The supernatant from the initial $1,000 \mathrm{~g}$ centrifugation step in the isolation of the chloroplast pellet was centrifuged for $2 \mathrm{~min}$ at $5,000 \mathrm{~g}$, transferred to a clean tube, and centrifuged for $5 \mathrm{~min}$ at $20,000 \mathrm{~g}$. The resulting mitochondrial pellet was resuspended in $200 \mu \mathrm{l}$ of $50 \mathrm{mM}$ TRIS/ $\mathrm{HCl}, \mathrm{pH}$ 8.0 , containing $14 \mathrm{mM}$ 2-mercaptoethanol and $0.3 \%$ Triton $\mathrm{X}-100$.

Data from the $F_{2}$ plants in each of six populations were tested for single-locus goodness of fit using chi-square. Deviations from random assortment and recombination frequencies for pairs of genes were determined using the LINKAGE-1 program of Suiter et al. ${ }^{10}$

\section{Results}

In all seven $F_{2}$ populations, segregation of morphological markers and isozyme phenotypes generally fit the expected $3: 1$ or 1:2:1 ratios (Table 2). Significant deviations from expected ratios were observed at several isozyme loci and one morphological trait. However, for each of the loci that displayed aberrant segregation within an $F_{2}$ family, ratios within the normal range $(P>.05)$ were obtained in at least two other $\mathrm{F}_{2}$ families. Some partial sterility was observed in the Giza 9/LO61 population, possibly reflecting chromosomal rearrangement.

The Mendelian segregation ratios shown by each of the allozyme polymorphisms indicated that each was coded by a single nuclear gene. In some cases these results represented confirmation of previous studies; however, other results were novel and are described in detail.

The four AAT isozymes (Figure 1) were located in different subcellular compartments, and each was encoded by a distinct locus. The fastest migrating isozyme, AAT1 , exhibited low activity relative to the other three isozymes. It was weakly associated with the mitochondrial pellet and, similar to all the other isozymes, was observed in the supernatant. Based on previous results in pea ${ }^{13,15}$ and Cucurbita, ${ }^{18}$ it was postulated to be of microbody origin. The coding locus was therefore designat- 
Table 2. Single-locus goodness of fit to either a $3: 1$ or_a 1:2:1 ratio for genes used in the linkage analyole

\begin{tabular}{|c|c|c|c|c|c|}
\hline \multirow[b]{2}{*}{ Family } & \multirow[b]{2}{*}{ Locus } & \multicolumn{3}{|c|}{ No. observed with designated phenotype } & \multirow[b]{2}{*}{$x^{2}$} \\
\hline & & $\begin{array}{l}\text { Dominant } \\
\text { or fast }\end{array}$ & Heterozygous & $\begin{array}{l}\text { Recessive } \\
\text { or slow }\end{array}$ & \\
\hline $\mathrm{Br} / \mathrm{LO}^{\circ}$ & $\begin{array}{l}\text { Gs } \\
Y c \\
G h \\
P i \\
\text { Aat-mb } \\
\text { Aat-p } \\
\text { Aat-c } \\
\text { Gat-I } \\
\text { Gal-2 } \\
\text { Fk } \\
\text { 6pgd-p } \\
\text { Skdh }\end{array}$ & $\begin{array}{r}40 \\
39 \\
32 \\
24 \\
19 \\
14 \\
7 \\
12 \\
8 \\
15 \\
15 \\
15\end{array}$ & $\begin{array}{l}- \\
- \\
- \\
- \\
23 \\
30 \\
35 \\
38 \\
14 \\
25 \\
23 \\
26\end{array}$ & $\begin{array}{r}16 \\
17 \\
15 \\
11 \\
12 \\
12 \\
14 \\
6 \\
16 \\
16 \\
18 \\
13\end{array}$ & $\begin{array}{l}0.38 \\
0.86 \\
1.20 \\
0.77 \\
3.00 \\
0.43 \\
5.25 \\
8.43^{\circ} \\
6.00^{\circ} \\
0.68 \\
2.11 \\
0.22\end{array}$ \\
\hline $\mathrm{Br} / \mathrm{LO} 66$ & $\begin{array}{l}\text { Yc } \\
G h \\
P_{1} \\
\text { Aat-p } \\
\text { Adh-I }\end{array}$ & $\begin{array}{r}41 \\
36 \\
26 \\
14 \\
8\end{array}$ & $\begin{array}{l}- \\
- \\
25 \\
27\end{array}$ & $\begin{array}{r}9 \\
10 \\
12 \\
11 \\
8\end{array}$ & $\begin{array}{l}1.31 \\
0.26 \\
0.88 \\
0.36 \\
2.81\end{array}$ \\
\hline $\mathrm{Br} / \mathrm{LO} 77$ & $\begin{array}{l}Y c \\
G h \\
P i \\
\text { Aat-mb } \\
\text { Aat-p } \\
\text { Gal-l } \\
6 p g d-p \\
P g m-p \\
F k\end{array}$ & $\begin{array}{r}29 \\
22 \\
17 \\
10 \\
9 \\
6 \\
13 \\
18 \\
10\end{array}$ & $\begin{array}{r}- \\
\overline{-} \\
13 \\
21 \\
8 \\
17 \\
12 \\
19\end{array}$ & $\begin{array}{r}8 \\
13 \\
9 \\
9 \\
9 \\
7 \\
7 \\
7 \\
7\end{array}$ & $\begin{array}{c}0.23 \\
2.75 \\
1.28 \\
1.19 \\
0.23 \\
1.29 \\
2.19 \\
11.72^{\star} \\
0.61\end{array}$ \\
\hline $\mathrm{Br} / \mathrm{LO} 59$ & $\begin{array}{l}Y c \\
G h \\
P i \\
\text { Aat-p } \\
\text { Gal-1 } \\
F k \\
\text { Pgm-p } \\
\text { Skdh }\end{array}$ & $\begin{array}{r}24 \\
24 \\
12 \\
10 \\
10 \\
9 \\
12 \\
14\end{array}$ & $\begin{array}{l}- \\
- \\
19 \\
19 \\
22 \\
12 \\
16\end{array}$ & $\begin{array}{r}12 \\
11 \\
10 \\
7 \\
7 \\
5 \\
12 \\
6\end{array}$ & $\begin{array}{l}1.33 \\
0.77 \\
4.91^{c} \\
0.61 \\
0.61 \\
2.67 \\
4.00 \\
4.00\end{array}$ \\
\hline G9/LO78 & $\begin{array}{l}\text { Gh } \\
\text { Pt } \\
\text { Aat-mb } \\
\text { Aat-m } \\
\text { Gal-1 } \\
\text { Gal-2 } \\
\text { Pgm-c } \\
\text { Pgm-p } \\
\text { Lap-1 } \\
\text { Gpt-c }\end{array}$ & $\begin{array}{r}19 \\
23 \\
18 \\
15 \\
12 \\
12 \\
10 \\
5 \\
10 \\
12\end{array}$ & $\begin{array}{l}- \\
14 \\
15 \\
19 \\
15 \\
17 \\
20 \\
15 \\
15\end{array}$ & $\begin{array}{r}10 \\
8 \\
4 \\
6 \\
5 \\
4 \\
8 \\
10 \\
11 \\
9\end{array}$ & $\begin{array}{c}1.39 \\
0.01 \\
12.70^{\circ} \\
5.50 \\
2.83 \\
4.16 \\
0.26 \\
2.14 \\
1.06 \\
1.50\end{array}$ \\
\hline G9/LO61 & $\begin{array}{l}Y c \\
P i \\
\text { Aat-mb } \\
\text { Lap-1 } \\
\text { Lap-2 } \\
\text { Pgm-c } \\
6 p g d-p \\
\text { Aldo } \\
\text { Skdh } \\
\text { Nag } \\
\text { Px-1 }\end{array}$ & $\begin{array}{r}21 \\
17 \\
12 \\
9 \\
6 \\
10 \\
9 \\
9 \\
15 \\
11 \\
7\end{array}$ & $\begin{array}{l}- \\
16 \\
23 \\
16 \\
17 \\
17 \\
17 \\
11 \\
17 \\
18\end{array}$ & $\begin{array}{r}12 \\
9 \\
8 \\
4 \\
6 \\
9 \\
10 \\
10 \\
10 \\
8 \\
11\end{array}$ & $\begin{array}{l}2.27 \\
1.28 \\
1.33 \\
4.17 \\
0.57 \\
0.17 \\
0.17 \\
0.17 \\
6.83 a \\
0.61 \\
0.88\end{array}$ \\
\hline RC/LO78 & $\begin{array}{l}\text { Aat-mb } \\
\text { Lap-1 } \\
\text { Gal-I } \\
P_{g m-c} \\
P_{g m-p} \\
\text { Fk } \\
\text { Gpi-c }\end{array}$ & $\begin{array}{r}27 \\
15 \\
7 \\
15 \\
10 \\
17 \\
19\end{array}$ & $\begin{array}{l}13 \\
38 \\
21 \\
22 \\
13 \\
32 \\
32\end{array}$ & $\begin{array}{r}10 \\
11 \\
9 \\
4 \\
12 \\
5 \\
13\end{array}$ & $\begin{array}{c}23.08^{\circ} \\
2.75 \\
0.64 \\
6.12 \\
2.54 \\
7.19 \\
1.12\end{array}$ \\
\hline
\end{tabular}

- Abbrevtations for families: Br/LO4 - Brewer/L. culinaris ssp. orientalis (No. 4); Br/LO66 - Brewer/L cullinaris ssp. orientalis (No. 66); Br/LO77 - Brewer/L. culinaris ssp. orientalis (No. 77); Br/LO59 = Brewer/L. culunaris ssp. orientalis (No. 59); G9/LO78 = Giza 9/L culinaris ssp. orientalis (No. 78); G9/LO61 - Giza 9/L culinaris ssp. odemensis (No. 61); RC/LO78 - Red Chief/L culinaris ssp. orientalis (No. 78).

$\circ P<.01$.

$c P<.05$

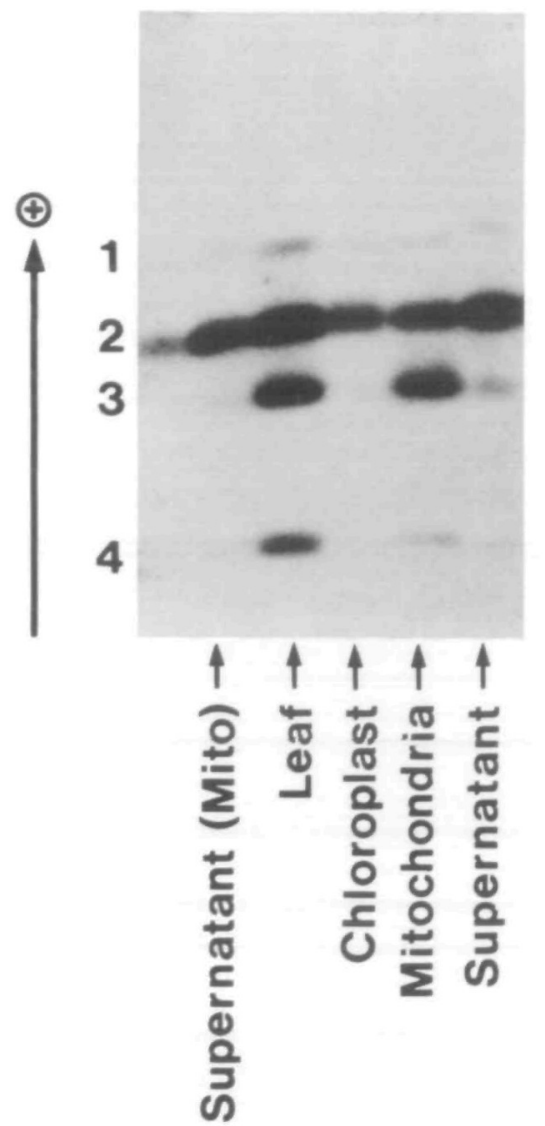

Figure 1. Subcellular compartmentalization of as partate aminotransferase in lentil. 1 = microbody; 2 = plastid; 3 = mitochondrial; $4=$ cytosolic.

ed Aat-mb to reflect this compartmentalization. AAT-2 was the plastid-specific isozyme coded by Aat-p. AAT-3 and AAT-4 appeared to be the mitochondrial and cytosolic forms on the basis of the following observations: 1) The two isozymes did not form hybrid dimers with each other or with either plastid or microbody isozymes, indicating a different subcellular localization for each. 2) AAT-3 was strongly associated with the mitochondrial pellet, whereas AAT-4 was not. 3) Extracts of root tissue showed a higher activity of AAT-3 (data not shown), paralleling a similar increase in the activity of the mitochondrial form in pea root extracts. The mitochondrial pellet obtained for lentil was contaminated by the plastid isozyme (Figure 1) because the centrifugation protocol used to obtain the plastid pellet did not remove all plastids from the extract However, contamination of the mitochondrial pellet by cytosolic enzymes should have been minimal because such enzymes would have remained in the supernatant. Only a very low activity of the cytosolic GPI isozyme, GPI-2, was observed in the mitochondrial pellet, indicating the low level of cytosolic 


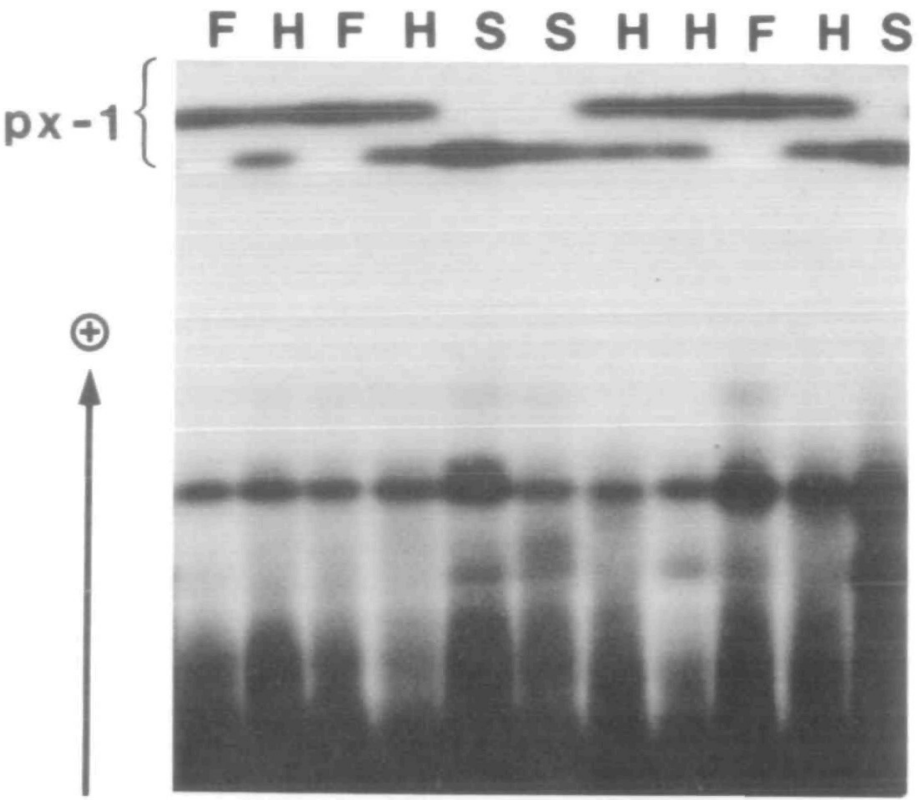

Figure 2. Peroxidase phenotypes for $P x-1$ obtained from extracts of lentll roots submerged in water for $18 \mathrm{~h}$ before extraction. Phenotype designations: $\mathrm{F}=$ fast; $\mathrm{S}=$ slow; $\mathrm{H}=$ heterozygous.

contamination. None of the AAT isozymes were observed in pollen leachates; again, this was similar to previous results in pea.

Only one isozyme each was resolved for ALDO and SKDH, both of which were located in the plastid compartment. In contrast, two isozymes each were resolved for GPI, 6GPD, and PGM. In all cases, using an analysis of pollen extracts, one was shown to be located in the cytosol (GPI-2, 6PGD-2, and PGM-1); the other isozyme was located in the plastid. Because allozyme polymorphism was observed for only four of the isozymes, only the loci Gpi-c, 6pgd-p, $P g m-c$, and $P g m-p$ could be rigorously defined by segregation analysis (Table 2). Two loci also were expressed in the ADH, GAL, and LAP enzyme systems. In ADH the familiar triplet of bands was observed in inbred lines. A variant in the more anodal ADH-1 was found in L. culinaris ssp. orientalis (No. 66), and the segregation pattern in the $\mathrm{Br} / \mathrm{LO} 66$ population confirmed that the variation was produced by allelic polymorphism at Adh-1. Both Lap-1 and Lap-2 exhibited normal segregation in the G9/LO61 family. In addition, Lap- 1 segregated in the G9/LO78 and RC/LO78 populations. The two isozymes of $\beta$-D-galactosidase displayed different $\mathrm{pH}$ optima and were best resolved in different buffer systems. The anodal isozyme with an alkaline pH optimum (GAL-1) produced sharp activity bands on the TRIS-HCl/lithium borate system, whereas the cathodally migrating isozyme (GAL-2) with an acid $\mathrm{pH}$ optimum was better resolved on the $\mathrm{pH}$ 6.1 gel. The loci encoding GAL-1 and GAL-2 were designated $\mathrm{Gal}-1$ and $\mathrm{Gal}-2$, respectively.

The most anodal zone of peroxidase activity, PX-1, displayed clear segregation in the G9/LO61 family (Figure 2). Other zones of activity did not differ between the parents. The fructokinase assay gave a single zone of activity that segregated in four $F_{2}$ populations. The locus responsible for this polymorphism was designated $F k$. A single NAG isozyme was observed in lentil extracts, encoded by the locus Nag.

\section{Linkages Observed}

Segregation data for individual loci and joint segregation of pairs of loci are shown in Table 3. A number of pairs of loci deviated significantly from random assortment. Recombination frequencies between pairs of loci were used to construct several linkage groups (Figure 3 ). The gene encoding for the plastid-specific form of phosphoglucomutase $(P g m-p)$ was closely linked to the gene for cotyledon color $(Y c)$ in two families that showed segregation concurrently for the two genes. In the $\mathrm{Br}$ / LO59 and $\mathrm{Br} / \mathrm{LO} 77$ families, the recombination fractions were $0 \%$ and $4 \%$, respectively, indicating very close linkage. The $Y c$ gene also appeared to be linked to the gene encoding for $\mathrm{N}$-acetylglucosaminidase ( $\mathrm{Nag}$ ) in the $\mathrm{Br} / \mathrm{LO} 66$ family; however, this linkage could not be confirmed in any of the other families.

The linkage of green epicotyl (Gs) with the plastid-specific form of aspartate aminotransferase (Aat-p) was found in the $\mathrm{Br}$ / LO4 family and is the same linkage reported previously by Zamir and Ladizinsky. ${ }^{19}$ Their data indicated that the two genes are 14 map units apart. Gs was also linked in their study to an isozyme of malic enzyme (Me-I); however, we did not observe segregation for $\mathrm{Me}-\mathrm{l}$ in any of the families we studied.

The locus coding the plastid-specific form of 6-phosphogluconate dehydrogenase ( $6 p g d-p)$ was linked to the gene encoding for fructokinase $(F k)$ in two of the

Table 3. Jolnt $F_{2}$ eegregation of pairs of locl that exhlbited algniflcant deviations from random aseortment

\begin{tabular}{|c|c|c|c|c|c|c|c|c|c|c|c|c|c|}
\hline \multirow[b]{2}{*}{ Loci } & \multirow[b]{2}{*}{ Family } & \multicolumn{10}{|c|}{ No. $F_{2}$ plants observed with designated phenotypes* } & \multirow{2}{*}{$\begin{array}{l}\text { Recombi- } \\
\text { nation } \\
\text { fraction }\end{array}$} & \multirow{2}{*}{ SE } \\
\hline & & $\mathbf{N}$ & $-1-$ & $-/ \mathrm{H}$ & $-1+$ & $\mathrm{H} / \mathrm{-}$ & $\mathrm{H} / \mathrm{H}$ & $\mathrm{H} /+$ & $+1-$ & $+/ \mathrm{H}$ & $+1+$ & & \\
\hline $\begin{array}{l}\text { Fk:6pgd-p } \\
\text { Gs:Aat-p } \\
\text { Aat-mb:Skdh }\end{array}$ & $\begin{array}{l}\mathrm{Br} / \mathrm{LO4} \\
\mathrm{Br} / \mathrm{LO4} \\
\mathrm{Br} / \mathrm{LO4}\end{array}$ & $\begin{array}{l}56 \\
56 \\
52\end{array}$ & $\begin{array}{r}13 \\
8 \\
6\end{array}$ & $\begin{array}{l}3 \\
8 \\
4\end{array}$ & $\begin{array}{l}0 \\
0 \\
3\end{array}$ & $\frac{4}{4}$ & $\frac{19}{15}$ & $\frac{2}{2}$ & $\begin{array}{l}1 \\
4 \\
2\end{array}$ & $\begin{array}{r}1 \\
22 \\
7\end{array}$ & $\begin{array}{r}13 \\
14 \\
9\end{array}$ & $\begin{array}{l}11 \\
22 \\
29\end{array}$ & $\begin{array}{l}3.2 \\
6.1 \\
5.6\end{array}$ \\
\hline $\begin{array}{l}Y_{c:} P_{g m-p} \\
F_{k}, 6 p g d-p\end{array}$ & $\begin{array}{l}\mathrm{Br} / \mathrm{LO} 77 \\
\mathrm{Br} / \mathrm{LO} 77\end{array}$ & $\begin{array}{l}37 \\
36\end{array}$ & $\begin{array}{l}7 \\
5\end{array}$ & $\begin{array}{l}1 \\
2\end{array}$ & $\begin{array}{l}0 \\
0\end{array}$ & $\frac{-}{1}$ & $\overline{13}$ & $\frac{-}{5}$ & $\begin{array}{l}0 \\
0\end{array}$ & $\begin{array}{r}11 \\
2\end{array}$ & $\begin{array}{r}18 \\
8\end{array}$ & $\begin{array}{r}4 \\
15\end{array}$ & $\begin{array}{l}3.0 \\
5.0\end{array}$ \\
\hline$Y_{c} \cdot P_{g m-p}$ & $\mathrm{Br} / \mathrm{LO} 59$ & 36 & 12 & 0 & 0 & - & - & - & 0 & 12 & 12 & 0 & 0.0 \\
\hline$A a t-m b: A a t-m$ & G9/LO78 & 36 & 3 & 1 & 0 & 3 & 9 & 2 & 0 & 5 & 13 & 16 & 4.8 \\
\hline $\begin{array}{l}\text { Nag:Px-I } \\
\text { Lap-I:Lap-2 } \\
\text { Aat-mb:Skdh } \\
\text { Fk:Pgm-c }\end{array}$ & $\begin{array}{l}\text { G9/LO61 } \\
\text { G9/LO61 } \\
\text { G9/LO61 } \\
\text { RC/LO78 }\end{array}$ & $\begin{array}{l}36 \\
28 \\
36 \\
38\end{array}$ & $\begin{array}{l}1 \\
3 \\
7 \\
2\end{array}$ & $\begin{array}{l}0 \\
0 \\
0 \\
3\end{array}$ & $\begin{array}{l}7 \\
0 \\
1 \\
0\end{array}$ & $\begin{array}{l}4 \\
2 \\
2 \\
1\end{array}$ & $\begin{array}{l}13 \\
15 \\
10 \\
16\end{array}$ & $\begin{array}{l}0 \\
1 \\
4 \\
3\end{array}$ & $\begin{array}{l}6 \\
1 \\
1 \\
1\end{array}$ & $\begin{array}{l}5 \\
1 \\
1 \\
1\end{array}$ & $\begin{array}{r}0 \\
5 \\
10 \\
11\end{array}$ & $\begin{array}{l}17 \\
12 \\
16 \\
14\end{array}$ & $\begin{array}{l}4.9 \\
4.6 \\
4.7 \\
4.3\end{array}$ \\
\hline
\end{tabular}

\footnotetext{
- - = recesstve phenotypes or homozygous slow; $\mathrm{H}=$ heterozygous; + $=$ dominant phenotype or homozygous fast.
} 


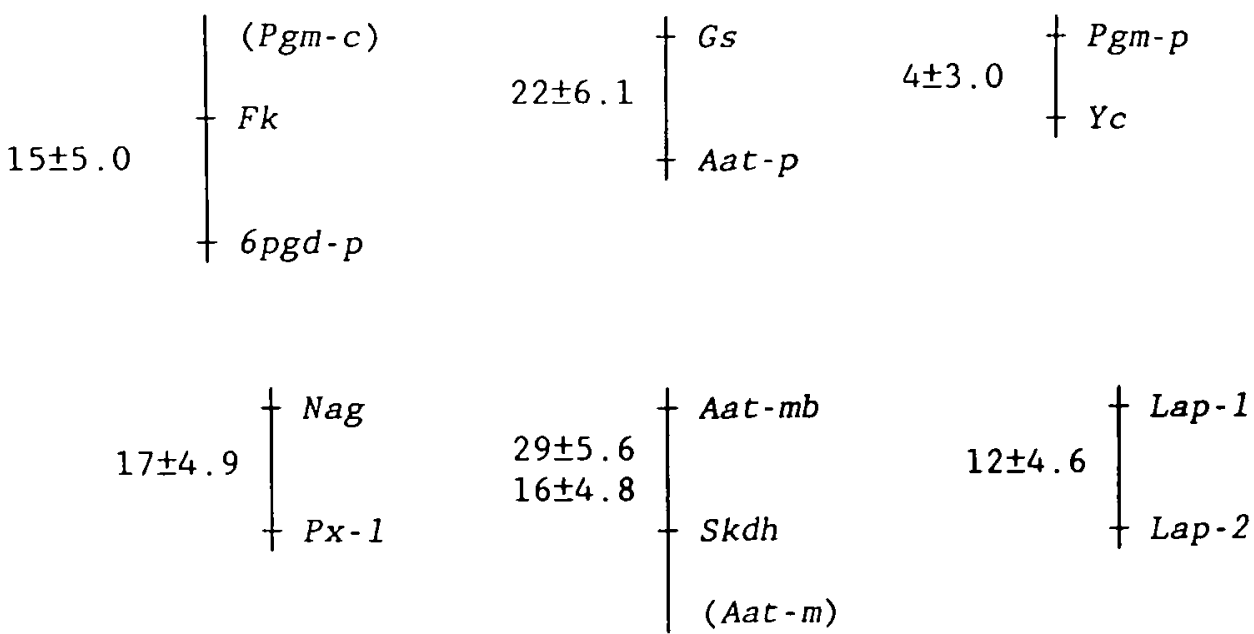

Flgure 3. Six linkage groups in lentil as determined by joint segregation of isozyme and morphological markers.

families. The recombination fractions were $15 \%$ and $11 \%$ in the $\mathrm{Br} / \mathrm{LO} 77$ and $\mathrm{Br} / \mathrm{LO} 4$ families, respectively. $\mathrm{Pgm}-\mathrm{C}$ also displayed linkage with $F k$ (Table 3 ) and belongs in this linkage group. Unfortunately, none of the families had all three loci segregating simultaneously, and so the sequence of the loci could not be determined unambiguously.

The loci Aat-mb, Aat-m, and Skdh constitute another set of linked loci for which the relative sequence could not be determined. Aat-mb and $S k d h$ displayed linkage in two segregating families (Br/LO4 and G9/LO61), with recombination fractions of $29 \%$ and $16 \%$, respectively. Aat-mb and Aat- $m$ showed a $16 \%$ recombination in the G9/LO78 family.

Two small linkage groups each containing two isozyme loci were identified in the G9/LO61 family (Table 3). The loci Nag and $P x-l$ showed a $17 \%$ recombination frequency, and Lap- 1 and Lap-2 were approximately 12 recombinant units apart.

\section{Discussion}

The genetics of lentil has only recently received much attention; however, these studies have revealed a large number of morphological genes and polymorphic isozyme loci. ${ }^{4,6,19}$ We used several of these genes as well as some undescribed variants in our study to identify six linkage groups, four of which have not been reported previously. Comparison of the isozyme phenotypes and linkages among loci found in Lens with those described in the garden pea (Pisum sativum L.) revealed a number of parallels, providing additional support for our linkage results. ${ }^{15,16}$ Four AAT isozymes have been identified in the garden pea, including one each in the microbody, the mitochondrion, the plastid, and the cytosol. ${ }^{13,15}$ Because the organelle isolation was more extensively performed in the pea studies, we used the results in pea to support our subcellular assignments of lentil AAT isozymes. In both genera the plastid isozyme is the most intensely staining isozyme in leaf extracts, whereas the microbody isozyme is the most anodal and displays the weakest activity. The relative mobilities of the AAT isozymes change slightly between the lentil and the pea. In the lentil the mitochondrial allozymes migrated slightly slower than or comigrated with the plastid allozymes, whereas in the pea the mitochondrial allozymes were always cathodal to the plastid forms and one allozyme comigrated with a cytosolic allozyme.

Other lentil enzyme systems, including ADH, ALDO, FK, GPI, 6PGD, NAG, PGM, and $S K D H$, are very similar to those in the pea, with homologous forms being easily identified. ${ }^{15,18}$ Similarly, the anodal $P x-I$ has its counterpart in Pisum (Figure $2 \mathrm{C}$ in reference 16). An anodal $\beta$-galactosidase with an alkaline $\mathrm{pH}$ optimum is also found in the pea, but the pea has two cathodal isozymes with acid $\mathrm{pH}$ optima. ${ }^{16}$ We have not found in lentil an isozyme corresponding to the Gal-3 of the pea.

The ease with which homologous isozyme loci can be identified between Lens and Pisum makes it possible to look for linkage groups that may be conserved between these two members of the Viceae. For instance, the locus coding the cytosolic PGM (Pgm-c) was linked to that coding the plastid 6PGD (6pgd-p) in the lentil, as it is in the pea. ${ }^{16}$ Tadmor et al. ${ }^{11}$ demonstrated that the locus coding the plastid-specific $6 P G D$ is linked to a locus cod- ing a peptidase. In the pea $6 p g d-p$ also shows linkage to a peptidase locus. ${ }^{16}$

Other linkages in the pea paralleling those reported here for lentil include that between $A a t-m$ and $S k d h^{15}$ and one between $P x-1$ and Nag. ${ }^{16}$ Finally, in the pea Lap-I and Lap-2 are both on chromosome 3 but are too far apart to display nonrandom assortment. ${ }^{15}$ The significant disparity in linkage distance between the two Lap loci in the two species would indicate that the parallel linkages are coincidental rather than conserved.

The clear parallel between enzyme systems in the lentil and the pea provides an opportunity to establish a consistent nomenclature for isozyme loci at least in the Viceae. Thus, we have used locus designations in the lentil that will clearly identify the homologous locus in Pisum. We feel that such a practice will promote interaction between geneticists and breeders working on these crops as well as on sweet pea (Lathyrus ssp.) and faba bean (Vicia faba), all members of the Viceae. In our system the Aat-1 of Skibinski et al. ${ }^{9}$ becomes Aat-p, and the Got-1, Got-2, and Got-3 of Tadmor et al." ${ }^{1}$ are equivalent to $A a t-m b, A a t-p$, and Aat-m, respectively. The practicality of this convention is particularly apparent in cases in which commercially important genes have been tagged by isozyme loci in one of the species. For instance, in the pea $\mathrm{Pgm}$-p has been shown to be a closely linked marker for the $M o$ gene, which confers resistance to bean yellow mosaic virus. ${ }^{17}$ Such closely linked markers can be used as tags for important genes in breeding programs.

The formulation of detailed gene maps should facilitate marker-assisted selection methods for these crops. It may also be possible to analyze the genetic variation present in germ plasm collections to synthesize segregating populations with unique combinations of traits.

\footnotetext{
References

1. Cardy BJ, Stuber CW, and Goodman MM. Techniques for starch gel electrophoresis of enzymes from maize (Zea mays L). Raleigh, North Carolina: North Carolina State University Department of Statistics Mimeo Serles No. 1317. 1980 .

2. Cayton JW, and Tretiak DN. Amine-citrate buffers for $\mathrm{pH}$ control in starch gel electrophoresis. J Fish Res Bd Can 1972; 29:1169-1172.

3. Cohen D, Ladizinsky G, Zlv M, and Muehlbauer FJ. Rescue of interspecific Lens hybrids by means of embryo culture. Plant Cell Tissue Organ Culture 1984; 3: 343-347.

4. Hoffman DL, Soltis DF, Muehlbauer FJ, and Ladizinsky G. Isozyme polymorphism in Lens (Leguminosae). Syst Bot 1986; 11:392-402.
} 
5. Ladizinsky G, Braun D, Goshen D, and Muehlbauer FJ. The biological species of the genus Lens. Bot Gaz $1984 ; 145: 253-261$.

6. Muehlbauer FJ, and Slinkard AE Genetics and breeding methodology. In: Lentils (Webb $C$ and Hawtin G, eds). London: Commonwealth Agricultural Bureau; 1981:69-90.

7. Selander RK, Smith MH, Yang, SY, Johnson WE, and Gentry JB. Biochemical polymorphism and systematics in the genus Peromyscus I. Variation in the oldfield mouse (Peromyscus polionotus). Austin: University of Texas Publication 7103. 1971:49-90.

8. Shaw CR, and Prasad R. Starch gel electrophoresisa compilation of recipes. Biochem Genet 1970; 4:297320.

9. Skjbinskd DOF, Rassol D, and Erskne W. Aspartate amino transferase allozyme varlation in a germplasm collection of the domesticated lentil (Lens culinans) Theor Appl Genet 1984; 68:441-448.
10. Suiter KA, Wendel JF, and Case JS. J Hered 1983; 74:203-204

11. Tadmor Y, Zamir D, and Ladizinsky G. Genetic mapping of an ancient translocation in the genus Lens. Theor Appl Genet 1987; 73:883-892.

12. Weeden NF, and Emmo AC. Isozyme characterization of Kentucky bluegrass cultivars. Can J Plant Sci 1985; 65:985-994.

13. Weeden NF, and Gottlieb LD. The genetics of chloroplast enzymes. J Hered 1980; 71:392-396.

14. Weeden NF, and Gottlieb LD. Isolation of cytoplasmlc enzymes from pollen. Plant Physiol 1980; 66: 400-403.

15. Weeden NF, and Marx GA. Chromosomal locations of twelve isozyme loci in Pisum sativum. J Hered 1984; 75:365-370.
16. Weeden NF, and Marx GA. Further genetic analysis and lintage relationships of isozyme loci in the pea. $J$ Hered 1987; 78:153-159.

17. Weeden NF, Provvidenti $R$, and Marx GA. An 1sozyme marker for resistance to bean yellow mosaic virus in Pisum sativum. J Hered 1984; 75:411-412.

18. Weeden NF, and Robinson RF. Allozyme segregation ratlos in the interspecific cross Cucumita maxima $\times C$ ecuadorensis suggest that hybrid breakdown is not caused by minor alteration in chromosome structure. Genettcs 1987; 114:593-609.

19. Zamir D, and Ladizinsky G. Genetics of allozyme variants and linkage groups In lentil. Euphytica 1984; 33:329-336. 